\title{
Beszámoló a 2016-os Európai Allergológus kongresszusról
}

\author{
Report on the 2016 Congress of the European Allergologists
}

\author{
Szerző: Réthy Lajos Attila® \\ Nemzeti Egészségfejlesztési Intézet
}

Beküldve: 2016.09.05.

Kulcsszavak: kongresszus, Európai Allergológiai- és Klinikai Immunológiai Akadémia, immunterápia, molekuláris allergia-diagnosztika, egészségfejlesztés

Keywords: congress, European Academy of Allergology and Clinical Immunology, immunotherapies, molecular allergy diagnostics, health development

\section{BEVEZETÉS}

Az allergia a „fejlett” világ egyik népbetegsége. Tankönyvi adat, hogy Európa, Észak-Amerika, Ausztrália népességének közel 30\%-a allergiás. Az allergológiai diagnosztika és terápia az utóbbi években robbanásszerú fejlődésen ment keresztül, különös tekintettel a molekuláris alapú diagnosztikára és az immáron oki kezelés lehetőségét nyújtó specifikus szublingvális immunterápiára. Mindezek különösen indokolttá teszik, hogy az allergológia eme korszerű módszereivel tisztában legyen minden egészségfejlesztéssel foglalkozó szakember is. A lehetőségek ismertetésére jó alapot nyújthatnak az európai Allergológiai és Klinikai Immunológiai Akadémia (EAACI) jubileumi, 60. éves kongresszusán elhangzott előadások eredményei.

A kongresszusra 2016. június 12-15 között került sor Bécsben, közel 7400 delegált részvételével. A szekciók párhuzamosan zajlottak az új kiállítási és kongresszusi központban közel húsz helyszínen. A témakörök főként a gyakorlati allergológia, kisebb részben a klinikai immunológia illetve a kísérletes immunológia területeit ölelték fel. ${ }^{1}$ A kongresszus mottójának - „Valcer allergénekkel” - megfelelően, színes „táncrendben” a tisztított allergén-komponensekkel kapcsolatos legkorszerúbb diagnosztikai és immunterápiás lehetőségeket, eredményeket ismer- hettük meg. A kongresszus fő témaköreinek megfelelően tekintsük át részletesebben az új trendeket az allergológiai diagnosztika- és terápia területén!

Az allergiás nátha kezelése - jelen és közeljövő

Jelen: Az allergiás nátha klasszikus kezelése A „klasszikus” terápia alapvetően tüneti kezelést jelent, főként antihisztamin készítmények bázisán. Ezek alkalmazása során az allergén kiváltotta hisztamin és más biológiailag aktív molekulák felszabadulásának gátlásával az előidézett tünetek visszaszorulnak. A régebbi antihisztamin készítményeket komoly mellékhatás-spektrum kísérte, elsősorban az álmosság. ${ }^{2}$ A korszerű, második generációs antihisztaminoknál ez a mellékhatás már egyáltalán nem jelentkezik. ${ }^{3}$ Azonban az antihisztamin terápiát gyakran ki kell egészíteni az orr nyálkahártya gyulladását tartósan csökkenteni képes, szteroid alapú gyulladáscsökkentő orrspray-vel, illetve antihisztamin tartalmú szemcseppel. ${ }^{4}$

Jelen és közeljövő: Az allergia oki kezelése, az allergén specifikus immunterápia (AIT)

Az allergén specifikus immunterápia (AIT) lényege a kiváltó allergénnel történő immuntolerancia-indukció, ami az allergia oki kezelését jelenheti. Ilyenkor az allergiát kiváltó anyag időben fokozatosan emel- 
kedő adagú kivonatát injekciós formában vagy nyelv alá cseppentve szoktatják hozzá az immunrendszert az adott anyag tolerálásához. Ennek során kedvező változás áll be a kórosan fokozott immunválaszban: az allergiás Th2 immunválasz eltolódik a reguláló T sejtek (T reg) dominanciájának irányába. Mindez következményes hízósejt és bazofil aktivitás csökkenéssel, fokozott specifikus lgG4 termeléssel és végül a specifikus lgE szintek csökkenésével jár. 3-5 egymást követő szezonnyi kezeléssel hosszú távú (1012 éves) tünetmentesség is elérhető. A terápia azt is megakadályozhatja, hogy a szénanátha mellett asztma is kialakuljon, illetve hogy a betegek más anyagra legyenek allergiásak. ${ }^{5,6}$

\section{Az AlT története}

Az első sikeres allergén-specifikus immunterápiát szénanátha ellen az első világháború előtti években végezték szubkután (bőr alatti) pázsitfú extraktummal. ${ }^{7,8} \mathrm{~A}$ szubkután immunterápia (SCIT) későbbi elterjedését az injekciós kezelés nehézsége mellett az alkalmankénti anafilaxiás halálesetek is gátolták. ${ }^{i, 7}$

\section{Szublingvális immunterápia (SLIT)}

Az 1980-as években adtak hírt először sikeres szublingvális (nyelv alatti) immunterápiáról (SLIT) poratkára allergiás betegeknél.7 Az elvégzett metaanalízisek szerint a SLIT hatékony lehet allergiás náthában illetve asztmában is. A Világ Allergológiai Társaság (WAO) és az Európai Allergológiai és Klinikai Immunológiai Társaság (EAACI) a SCIT és SLIT indikációját lényegileg azonosnak minősítette., ${ }^{5,6,9}$ Ugyanakkor fontos kiemelni, hogy egyenrangúságuk mellett a SLIT biztonságossága és tolerálhatósága kedvezőbb spektrumú, mint a SCIT-é. A SLIT esetében lényegesen kevesebb, enyhébb mellékhatásokkal kell csak számolni, emellett alkalmazása során anafilaxiás reakcióból származó halálesetet nem írtak le. A ritka helyi mellékhatások (pl. enyhe égető vagy diszkomfort érzés a szájban) mellett a kezelést nem kell félbeszakítani, orális antihisztamin általában elegendő a tünetekre. Az esetleg fellépő gasztorintesztinális (gyomor-bélrendszeri) panaszok esetén az oldatot lenyelés he- lyett érdemes kiköpni a bevételt követő pár perc leteltével. Felléphetnek még az allergia szezonra jellemző szénanáthás, asztmás tünetek is. Kontrollált asztma nem ellenjavallata a kezelésnek. Az eddig alkalmazott SLIT kezelések mellett anafilaxiás halálesetet eddig több millió a világon folytatott SLIT kezelés ellenére sem regisztráltak. Előzetes anafilaxia más allergénre, illetve megelőző szubkután immunterápia esetén mindazonáltal óvatosságra inthet, ez lehet relatív kontraindikáció. ${ }^{10}$

\section{SLIT-ellenjavallatok}

Dekompenzált, nem kontrollált asztma, béta blokkoló kezelés, láz, akut fertőző betegség, kifejezetten intenzív fizikai aktivitás a dózis beadása utáni órákban. A kezelés halasztását indokolhatja akut szájsebészeti beavatkozás, nyílt seb a szájüregben. Autoimmun betegség inkább csak elvi ellenjavallat, egyensúlyban lévő autoimmun betegeknél a kezelés általában nem jelent problémát. Várandósság esetén célszerű a kezelőorvossal konzultálni a módszer alkalmazásáról.., 6

\section{SLIT- hozzáférhetőség}

Jelenleg több jó minőségű szublingvális immunterápiás készítmény is rendelkezésre áll, mind a különböző pollenallergiák, mind egyéb inhalatív allergének okozta allergiák (pl. poratka, állati szőrök, stb.) kezelésére.

TB-támogatás sajnos egyelőre nincsen a készítményeken. A receptre kapható, törzskönyvezett készítmények mellett egyedi igénylésre rendelhető termékek is hozzáférhetők az országban. Az utóbbiak esetében a kezelőorvos javaslata alapján az Országos Gyógyszerészeti Intézet (OGYÉI) engedélyezi az alkalmazást. Fontos gyakorlati újdonság, hogy az OGYÉl engedély és a recept birtokában immár közvetlenül a nagykereskedőtől is rendelhet bármelyik gyógyszertár egyedi engedélyhez kötött szublingvális immunterápiás készítményt.

A szublingvális immunterápia igazolt hatékonysága alapján számos európai országban élvez társadalombiztosítási támogatást (hazánkban egyelőre még nincs így).

\footnotetext{
i Az anafilaxia az allergia legsúlyosabb tünetegyüttese, életveszélyes klinikai állapotot jelent. Lényege, hogy az allergiás egyén szervezetébe jutó allergén hatására nagy mennyiségben szabadulnak fel gyulladáskeltő kémiai anyagok a sejtekből és a szövetekből. Ezek az anyagok, a hisztamin és az ahhoz hasonló ún. biogén aminok olyan súlyos keringési és légzési zavart okoznak, amely eszméletvesztéshez, sürgős orvosi ellátás hiányában halálhoz vezet.
} 
Korszerű, molekuláris (komponens alapú) allergiadiagnosztika az immunterápia hatékonyságának növelése érdekében.

A legújabb nemzetközi ajánlások légúti allergiákban a szublingvális immunterápia (SLIT) elvégzése előtt a molekuláris (komponens alapú) allergia tesztelést (Component-Resolved Diagnosis: CRD) ajánlják. ${ }^{11}$ A pollenek, a poratka, de más allergiát okozó anyagok, így egyes ételek, rovarmérgek stb. is több, allergiát okozó molekulát (komponenseket) tartalmaznak. Amíg a hagyományos allergiatesztek az allergiát kiváltó anyag (allergén komplex) teljes kivonatával szemben mérik a specifikus IgE szintet, addig a komponens alapú vizsgálat célja annak igazolása, hogy kimutatható-e emelkedett IgE szint az allergén komplex egyes komponenseire vonatkozólag. ${ }^{12}$

Az immunterápia a jelenleg rendelkezésre álló készítményekkel akkor lehet a leginkább hatékony, ha az allergia a fő komponensre áll fenn és mellékkomponensekre nem. Utóbbiak ellen nem igazán hatékony az immunterápia, ezért ilyen esetekben a terápia kimenetele kétségesebb. Nyírallergia, fúkeverék-allergia, parlagfü-allergia, fekete üröm allergia esetén tervezett immunterápia előtt mindenképpen ajánlott tehát a CRD alkalmazása. ${ }^{11}$

Pollen allergiáknál gyakran megfigyelhető hogy a fő allergén-komponens(ek) mellett vagy helyett, egy vagy több olyan mellék-komponens is kivált specifikus IgE választ, ami más pollenekben, vagy éppen gyümölcsökben is előfordulhat. Utóbbiak lehetnek felelősek a pollen-étel keresztallergiák, orális allergia szindrómák kialakulásáért (pl. nyír-barack, parlagfü-dinnye stb.). Porakta allergiásoknál hasonló jelenség figyelhető meg rák fogyasztás kapcsán, közös atka-rák komponensek miatt. ${ }^{13}$

A CRD diagnosztikát táplálék allergiák és méh/darázs allergia esetében is sikeresen alkalmazzák Európa szerte. Alkalmazásával megbecsülhető egy étel- vagy rovarméreg allergia várható jövőbeni viselkedése, az allergiás reakció szempontjából koc- kázatosabb illetve ártalmatlanabb komponensekre termelt IgE ellenanyag jelenléte/hiánya alapján. Például a földimogyoró ara h2 komponensre kimutatott specifikus IgE jelenléte jelezheti az anafilaxiaveszélyt. ${ }^{13} \mathrm{~A}$ CRD Magyarországon is elérhető már néhány allergia centrumban, igaz sajnos egyelőre csupán térítés ellenében, akárcsak maga a szublingvális immunterápia. Azonban egy 3-5 évig terjedő SLIT terápia jelenlegi viszonylag magas költségei miatt kifizetődőbb előre megvizsgálni, hogy várható-e elfogadható eredmény a több éves immunterápiától.

\section{ÖSSZEFOGLALÁS}

Az allergiás megbetegedések közel harminc százalékos prevalenciája a teljes népesség körében indokolttá teszi, hogy az egészségfejlesztésben dolgozó szakemberek is megismerkedjenek az allergológiai diagnosztika és terápia korszerú lehetőségeivel. Az elmúlt évek robbanásszerű fejlődése tette lehetővé a molekuláris - komponens alapú - allergia diagnosztika (CRD) és a szublingvális immunterápia (SLIT) elterjedését. Mindezen lehetőségek legfrissebb nemzetközi ismertetésére az Európai Allergológiai és Klinikai Immunológiai Akadémia (EAACI) jubileumi, 60. éves kongresszusán került sor 2016 nyarán.

A SLIT az allergiák oki kezelését jelenti a klasszikus tüneti kezeléshez képest. A CRD allergia-diagnosztika alkalmazásával fokozható a SLIT terápiás eredményessége, kimutathatóak kereszt-allergiák és megbecsülhető a táplálék- és rovarméreg allergiák várható jövőbeni súlyossága is.

Mindezek áttörést jelentenek az eddigi, hagyományos diagnosztikai és terápiás lehetőségekhez képest. Az új módszerek ismerete, propagálása mind szakmai, mind társadalmi színtéren segíthet a költséghatékony szakmapolitikai döntések meghozatalában éppúgy, mint a társadalmi egészségismeretek elmélyítésében, az egészségtudatosság további fejlesztésében.

\footnotetext{
${ }^{1}$ Scientific Programme | EAACI Congress 2016 Available from: http://www.eaaci2016.org/scientific-programme/ (Elérve: 2016. 08. 17.)

${ }^{2}$ Kalpaklioglu F, Baccioglu A. Efficacy and safety of H1-antihistamines: an update. Anti-Inflamm Anti-Allergy Agents Med Chem. 2012;11(3):230-7.

${ }^{3}$ Riechelmann H. [Oral second generation antihistamines in allergic rhinitis]. Laryngorhinootologie. 2005 Jan;84(1):3041.
} 
${ }^{4}$ Braido F, Sclifò F, Ferrando M, Canonica GW. New therapies for allergic rhinitis. Curr Allergy Asthma Rep. 2014 Apr;14(4):422.

${ }^{5}$ EAACl - Consensus Documents Available from: http://www.eaaci.org/resources/scientific-collaborations/consensusdocuments.html (Elérve: 2016. 08. 17.)

${ }^{6}$ Canonica GW, Cox L, Pawankar R, Baena-Cagnani CE, Blaiss M, Bonini S, et al. Sublingual immunotherapy: World Allergy Organization position paper 2013 update. World Allergy Organ J Available from: http://dx.doi.org/10.1186/1939-4551-76 (Elérve: 2016. 08. 17.)

${ }^{7}$ Ring J, Gutermuth J. 100 years of hyposensitization: history of allergen-specific immunotherapy (ASIT). Allergy. 2011 Jun;66(6):713-24.

${ }^{8}$ Noon L. Prophylactic inoculations against hay fever. Lancet 1911;1:1572-1573.

${ }^{9}$ Jutel M, Agache I, Bonini S, Burks AW, Calderon M, Canonica W, et al. International consensus on allergy immunotherapy. J Allergy Clin Immunol. 2015 Sep;136(3):556-68.

10 SLIT with prior anaphylaxis | AAAAI The American Academy of Allergy, Asthma \& Immunology. Available from: http://www.aaaai.org/ask-the-expert/slit-anaphylaxis (Elérve: 2016. 08. 17.)

${ }^{11}$ Pfaar O, Bachert C, Bufe A, Buhl R, Ebner C, Eng P, et al. Guideline on allergen-specific immunotherapy in IgE-mediated allergic diseases: S2k Guideline of the German Society for Allergology and Clinical Immunology (DGAKI), the Society for Pediatric Allergy and Environmental Medicine (GPA), the Medical Association of German Allergologists (AeDA), the Austrian Society for Allergy and Immunology (ÖGAI), the Swiss Society for Allergy and Immunology (SGAI), the German Society of Dermatology (DDG), the German Society of Oto- Rhino-Laryngology, Head and Neck Surgery (DGHNO-KHC), the German Society of Pediatrics and Adolescent Medicine (DGKJ), the Society for Pediatric Pneumology (GPP), the German Respiratory Society (DGP), the German Association of ENT Surgeons (BV-HNO), the Professional Federation of Paediatricians and Youth Doctors (BVKJ), the Federal Association of Pulmonologists (BDP) and the German Dermatologists Association (BVDD). Allergo J Int. 2014;23(8):282-319.

12 Eigenmann PA, Atanaskovic-Markovic M, O’B Hourihane J, Lack G, Lau S, Matricardi PM, et al. Testing children for allergies: why, how, who and when: an updated statement of the European Academy of Allergy and Clinical Immunology (EAACI) Section on Pediatrics and the EAACl-Clemens von Pirquet Foundation. Pediatr Allergy Immunol Off Publ Eur Soc Pediatr Allergy Immunol. 2013 Mar;24(2):195-209.

${ }^{13}$ Matricardi PM, Kleine-Tebbe J, Hoffmann HJ, Valenta R, Hilger C, Hofmaier S, et al. EAACI Molecular Allergology User's Guide. Pediatr Allergy Immunol Off Publ Eur Soc Pediatr Allergy Immunol. 2016 May;27 Suppl 23:1-250. 